\title{
MONUMEN PERANG JAGARAGA DI DESA JAGARAGA SEBAGAI SUMBER BELAJAR IPS DI SMP NEGERI 1 SAWAN KECAMATAN SAWAN KABUPATEN BULELENG
}

\author{
Meri Yuliani ${ }^{1}$, Nengah Bawa Atmaja ${ }^{2}$, Tuty Maryati ${ }^{3}$ \\ Program Studi Pendidikan IPS Universitas Pendidikan Ganesha \\ Singaraja \\ e-mail: $\underline{\text { meriyuliani73@gmail.com }}{ }^{1}, \underline{\text { nengahbawaatmaja@yahoo.co.id }}^{2}$, tuty.maryati@undiksha.ac.id $^{3}$
}

\begin{abstract}
Abstrak
Monumen adalah bangunan atau tempat yang mempunyai nilai sejarah yang penting dan karena itu dipelihara dan dilindungi oleh Negara. Agar generasi selanjutnya mengenang dan menghormati jasa para pahlawan serta mampu mengaplikasikan nilai-nilai sejarah yang terkandung di dalamnya. Monumen ini juga dijadikan sebagai sumber belajar IPS pada jenjang SMP. Tujuan penelitian ini adalah untuk mengetahui latar belakang, nilai-nilai karakter, dan integrasi nilai-nilai karakter pada Monumen Perang Jagaraga yang dijadikan sebagai sumber belajar untuk siswa SMP Negeri 1 Sawan. Penelitian ini adalah penelitian deskriptif kualitatif. Sumber data dalam penelitian ini adalah informan, Tempat dan peristiwa, Arsip dan Dokumen. Metode pengumpulan data yang digunakan adalah observasi, wawancara dan dokumentasi. Hasil penelitian ini menunjukkan bahwa Sejarah perang jagaraga dilatar belakangi oleh dihapuskannya hak tawan karang oleh pihak Belanda akan tetapi Raja Buleleng tidak setuju sehingga terjadilah perang Jagaraga pada tahun 1849 . Terdapat beberapa nilai-nilai karakter pada diorama-diorama yang ada pada monumen Perang Jagaraga yakni: nilai religius, jujur, toleransi, kerja keras, kreatif, semangat kebangsaan, cinta tanah air, bersahabat atau komunikatif, cinta damai dan bertanggung jawab. Monumen perang Jagaraga digunakan sebagai sumber belajar IImu Pengetahuan Sosial (IPS) di SMP yang penerapannya dilakukan dengan menyesuaikan pada Kompetensi dasar di dalam Rencana Perangkat Pembelajaran yang digunakan dalam kegiatan pembelajaran.
\end{abstract}

Kata kunci: Monumen, Sejarah Perang Jagaraga, Sumber Belajar IImu Pengetahuan Sosial

\begin{abstract}
Monument is a place that has an important historical value and therefore is maintained and protected by the State. In order for the next generation to remember and respect the services of the heroes and to be able to apply the historical values contained in the construction of the monument is the purpose of the construction of the monument, in the case of the jagaraga war struggle monument. This monument is also used as a source of social studies learning at the junior high school level. The purpose of this study was to determine the background, character values, and integration of character values at the Jagaraga War Monument which was used as a learning resource for student of SMP Negeri 1 Sawan. This research is a qualitative descriptive study. Sources of data in this study are informants, places and events, and archives and documents. Data collections used are observation, interviews and documentation. The results of this study indicate that the history of the jagaraga war was motivated by the abolition of coral reef rights by the Dutch but the King of Buleleng disagreed so that the Jagaraga war occurred in 1849. There are several character values in the dioramas that are in the jagaraga war monument, namely: religious values, honesty, tolerance, hard work, creative, nationalistic spirit, homeland love, friendship or communicative, peaceful and responsible. Jagaraga war monument is used as a source of social sciences learning in junior high school whose application is done by adjusting to basic competencies in the lesson plan used in learning activities

Keywords : Monument, Jagaraga War History, Social Sciences Learning Resource
\end{abstract}

\section{PENDAHULUAN}

Bangsa Indonesia sebagai bangsa yang besar selalu menghargai jasa pendahulunya yang berjasa terhadap perkembangan bangsanya. Tentu kita tidak ingin disebut orang yang berjiwa kerdil, karena kita memang memiliki kemampuan untuk menghargai dan menghormati para pahlawan yang telah mengorbankan jiwa raganya untuk nusa dan bangsa (Tirtayasa,1994: 5). Revolusi yang menjadi alat tercapainya kemerdekaan bukan hanya kisah sentral dalam sejarah indonesia, melainkan merupakan unsur yang kuat dalam persepsi Bangsa Indonesia tentang dirinya sendiri. Paska proklamasi 17 agustus 1945 untuk 
pertama kalinya didalam kehidupan kebanyakan rakyat Indonesia, segala sesuatu yang serba paksaan yang berasal dari kekuasaan asing hilang secara tiba-tiba. Tidaklah mengherankan apabila hasilnya bukanlah munculnya suatu bangsa baru yang seras, melainkan suatu pertarungan sengit diantara individu-individu dan kekuatan-keuatan sosial yang bertentangan.

Salah satu tempat yang pernah menjadi areal pertempuran antara para pejuang Bali yaitu daerah Jagaraga, Bueleng, Bali. Perjuangan yang dilakukan para pejuang memberi kenangan yang mendalam bagi sebagian besar masyarakat Bali, khususnya di Desa Jagaraga yang merupakan salah satu desa yang ikut ambil bagian dalam mempertahankan wilayah Bali pada waktu 1846-1849. Perang Jagaraga adalah perang yang terjadi antara rakyat Bali dan Belanda pada tahun 1844 yang dilatarbelakangi oleh perampasan kapalkapal yang rusak atau karam di pantai Sangsit dan pantai Perancah di wilayah Jembrana. ini merupakan rangkaian sebab terjadinya Perang Buleleng dan Perang Jagaraga yaitu sebagai bukti keberanian Rakyat Bali mempertahankan adat agar undang-undang tawan karang tetap dijalankan. Hak tawan karang ini merupakan peraturan yang menguntungkan kepada masyarakat pesisir. Dengan hak tawan karang ini kerajaan-kerajaan tersebut dapat mempertahankan motif-motif ekonomis. Menurut hak tawan karang semua muatan kapal menjadi milik rakyat dan penduduk pantai sedangkan penumpangnya dijual belikan, dijadikan budak dan kadang-kadang dibunuh. Undang-undang tawan karang bukan hanya berlaku bagi kapal-kapal asing saja tetapi juga bagi kapal-kapal dari Kerajaan Bali sendiri. Muatan dan penumpang kapal yang terdampar akan diserahkan kepada Raja tempat asal kapal itu dan dalam jangka waktu 25 hari ada kesempatan untuk menebus muatan dan penumpang kapal. Jadi, uang tebusan diterima oleh raja perairan tempat kapal terdampar dan oleh penduduk pantai yang turut menyelamatkan penumpang dan muatan itu. Akan tetapi pihak Belanda ingin menghapuskan hak tawan karang dan ditolak oleh raja Buleleng sehingga terjadi pertempuran anatara Rakyat Bali melawan Belanda.

Akan tetapi Pada saat terjadinya pertempuran dari tahun 1846-1849 Patih Jelantik dan istrinya Jro Jempiring gugur dalam Perang Puputan Jagaraga. Untuk mengenang dan menghormati jasa para pahlawan yang gugur, dibangun sebuah monumen perjuangan yang disebut Monumen Perang Jagaraga. Monumen ini berdiri dengan megahnya di Desa Jagaraga. Monumen ini dibangun atas prakarsa para pejuang kemerdekaan dan Masyarakat Desa Jagaraga. Dukungan datang dari semua pihak, selain dari Masyarakat Desa Jagaraga serta Pemerintah Daerah Bali, Pemerintah Daerah Buleleng. Monumen ini diresmikan pada akhir tahun 2016 dan diresmikan oleh Bupati Buleleng Putu Agus Suradnyana.

Monumen adalah bangunan atau tempat yang mempunyai nilai sejarah yang penting dan karena itu dipelihara dan dilindungi oleh Negara. Monumen juga diartikan dengan bangunan (berupa tugu) sebagai peringatan suatu peristiwa dalam sejarah. Dalam bahasa Inggris monumen dikenal dengan istilah "memorial" yang memiliki pengertian tanda peringatan berbentuk tugu, patung dan sejenisnya, tetapi juga bisa diterapkan untuk upacara peringatan. Dengan demikian monumen tidak harus berarti benda, tetapi juga berarti peringatan akan peristiwa tertentu.

Tujuan dari pembangunan monumen tersebut agar generasi selanjutnya mengenang dan menghormati jasa para pahlawan serta mampu mengaplikasikan nilai-nilai sejarah yang terkandung di dalam pembangunan monumen tersebut. Seperti nilai rela berkorban demi kepentingan orang banyak, semangat pantang menyerah, semangat persatuan dan kesatuan hingga mencapai cita-cita merebut kemerdekaan. Cinta tanah air dan cita-cita membentuk Negara Kesatuan Republik Indonesia.

Monumen yang berdiri di kawasan Desa Jagaraga ini, merupakan salah satu sumber belajar IPS yang bisa digunakan sebagai media pembelajaan dikalangan siswa khususnya SMP hal ini di dukung oleh adanya KD (Kompetensi Dasar) IPS untuk SMP pada silabus kurikulum KTSP. Khusus untuk Monumen Jagaraga sangat cocok diterapkan dikelas VIII pada "KD 5.2 yaitu mendeskripsikan peristiwa-peristiwa sekitar proklamasi dengan materi pokok tindakan heroik diberbagai daerah".

Selain itu, Monumen Jagaraga sebagai sumber belajar IPS Pembelajaran akan lebih bermakna adalah jika pembelajaran menempatkan siswa sebagai pusat pembelajaran 
student centered daripada teacher centered. Belajar bukan sekedar kegiatan pasif menerima materi dari guru, melainkan proses aktif menggali pengalaman lama, mencari dan menemukan pengalaman baru serta menghubungkan antara keduanya sehingga membentuk makna. Makna tercipta dari apa yang siswa lihat, dengar, rasakan, dan alami. Untuk guru, mengajar adalah kegiatan memfasilitasi siswa dalam mengkonstruksi sendiri pengetahuannya lewat keterlibatannya dalam kegiatan pembelajaran. Dengan kata lain, sebagian besar waktu proses pembelajaran berlangsung dengan berbasis pada aktivitas siswa (Sanjaya, 2007:89).

Monumen Perang Jagaraga yang terletak di Desa Jagaraga merupakan bentuk perhatian dan aprsiasi kepada I Gusti Ketut Jelantik di Kabupaten Buleleng. Didalam Monumen Perang Jagaraga, I Gusti Ketut Jelantik dan sang istri Jero Jempiring diabadikan dalam sebuah patung yang mengisahkan tentang perjuangan mereka saat Perang Jagaraga berlangsung. Selain itu didalam Monumen Perang Jagaraga juga terdapat diorama-diorama yang menceritakan kisah perjuangan I Gusti ketut Jelantik dalam Perang Jagaraga.

SMP Negeri 1 Sawan merupakan salah satu sekolah yang berada di Desa Sawan Kecamatan Sawan. SMP Negeri 1 Sawan merupakan SMP yang selalu mengedepankan kedisiplinan. Saat ini di SMP Negeri 1 Sawan sudah dilakukan usaha penanaman nilai karakter kepada siswanya. Namun, penanaman nilai karakter yang diberikan masih belum maksimal. Model penanaman nilai karakter yang diberikan masih berupa teori yang hanya tercetak pada RPP (Rencana Pelaksanaan pembelajaran) guru saja, selain itu, guru masih sebatas memberikan materi yang terdapat dalam buku ajar dan berpatokan pada silabus pegangan. Bahkan, dalam pembelajaran IPS guru belum menggunakan sumber belajar lain selain buku ajar. Sumber belajar yang digunakan dalam pembelajaran IPS masih monoton, berupa buku ajar.

Pemanfaatan situs bersejarah di Jagaraga telah didukung oleh adanya KD (Kompetensi Dasar) yaitu mendeskripsikan peristiwa-peristiwa sekitar proklamasi yang sesuai dengan situs yang tersedia di Jagaraga. Ketersediaan situs bersejarah yang dapat digunakan sebagai sumber belajar seharusnya dapat dimanfaatkan secara efektif untuk mendukung peningkatan kualitas pembelajaran IPS. Kurangnya perhatian dari warga setempat maupun pemerintah, menyebabkan Monumen yang ada menjadi semakin kehilangan nilai historisnya.

Situs sejarah merupakan salah satu bagian dari lingkungan sekitar yang memiliki potensi sebagai sumber belajar. Desa jagaraga sebagai salah satu desa yang memiliki beberapa monumen seharusnya mampu memanfaatkan potensi tersebut secara efektif untuk mendukung peningkatan kualitas pembelajaran IPS di SMP. Oleh karena itu, dengan adanya monumen perang jagaraga ini, dapat dijadikan sebagai sumber bellajar oleh siswa dalam pembelajaran IPS, terutama di SMP Negeri 1 Sawan.

Tujuan penelitian ini adalah untuk mengetahui bagaimana latar belakang, nilai-nilai karakter, dan integrasi nilai-nilai karakter pada Monumen Perang Jagaraga yang dijadikan sebagai sumber belajar untuk siswa SMP Negeri 1 Sawan.

\section{METODE}

Penelitian ini adalah penelitian deskriptif kualitatif. Margono (2003), menyatakan bahwa penelitian deskriptif kualitatif merupakan penelitian yang memberikan informasi secara sistematis dan cermat tentang fakta-fakta aktual dan sifat populasi tetentu. Lokasi penelitian dilakukan di Monumen Perang Jagaraga Desa Jageraga, Kecamatan Sawan, Bueleng, Bali.

Sumber data dalam penelitian ini adalah informan, Tempat dan peristiwa, Arsip dan Dokumen. Metode pengumpulan data yang digunakan adalah observasi yang bertujuan untuk mengamati langsung objek penelitian, wawancara, studi dokumentasi. Instrumen yang digunakan adalah pedoman wawancara dan observasi. Metode yang digunakan untuk validasi/kesahihan data adalah triangulasi. Selanjutnya metode yang digunakan untuk analisis data adalah deksriptif kualitatif dengan 3 tahap yakni, reduksi data, penyajian data, dan kesimpulan. 


\section{HASIL DAN PEMBAHASAN \\ Sejarah Monumen Perang Jagaraga}

Jagaraga adalah nama sebuah desa dalam wilayah Kerajaan Buleleng, Bali Utara, kemudian menjadi masyur setelah dipakai sebagai pusat pertahanan prajurit Bali dalam menghadapi serangan serdadu-serdadu Belanda. Sebenarnya Perang Jagaraga adalah lanjutan dari Perang Buleleng yang terjadi pada tahun 1846, sedang pada tahun 1848 dan 1849 umumnya disebut Perang Jagaraga.

Soehartono dalam Perang Jagaraga (1973:211), kerajaan ini merupakan rangkaian sebab terjadinya Perang Buleleng dan Perang Jagaraga yaitu sebagai bukti keberanian Rakyat Bali mempertahankan adat agar undang-undang tawan karang tetap dijalankan. Jika dilihat dari sudut pandang ekonomi, hak tawan karang ini merupakan peraturan yang menguntungkan kepada masyarakat pesisir. Dengan hak tawan karang ini kerajaan-kerajaan tersebut dapat mempertahankan motif-motif ekonomis. Menurut hak tawan karang semua muatan kapal menjadi milik rakyat dan penduduk pantai sedangkan penumpangnya dijual belikan, dijadikan budak dan kadang-kadang dibunuh.

Awal Perang Buleleng dimulai saat Residen Maijor datang sendiri ke Bali pada bulan mei 1845 untuk meratifisir perjanjian penghapusan tawan karang. Permintaan Maijor tersebut ditolak oleh Raja Buleleng dan penolakan ini adalah satu sebab terjadinya Perang antara kerajaan Buleleng dengan Pemerintah Hindia Belanda.

Soegianto (2011: 52) menyatakan bahwa jatuhnya Kerajaan Buleleng ke tangan Belanda setelah Perang Buleleng pada bulan juni 1846, atas desakan Patih I Gusti Ketut Jelantik, Raja Buleleng memutuskan untuk mengundurkan diri Bersama-sama dengan laskar dan rakyat yang masih setia Raja dan Patih Jelantik mengundurkan diri ke arah timur dengan tujuan Desa Jagaraga. Sambil mundur sisa laskar dan rakyat tetap melakukan perlawanan terhadap serdadu Belanda.

Ada beberapa alasan yang telah mendesak Patih Jelantik untuk mengambil keputusan mengundurkan diri ke Jagaraga adalah Patih Jelantik menyadari bahwa kondisi persenjataan pasukannya tidak seimbang dengan persenjataan Belanda, sehingga akan sia-sia melanjutkan pertempuran. Untuk menghindari korban yang lebih banyak Patih Jelantik memerintahkan masa laskar dan rakyat yang tetap setia mundur ke Desa Jagaraga.

Desa Jagaraga merupakan daerah yang kaya akan hasil bumi yang sangat diperlukan dalam memenuhi perbekelan laskar Buleleng dalam jangka waktu yang panjang selama perang berlangsung. Desa Jagaraga merupakan penghasil beras dengan kualitas yang baik. Selain itu faktor lainnya adalah pelabuhan yang ada di Pantai Sangsit merupakan jalur perdagangan yang dgunakan sebagai tempat bongkar barang.

Dalam Perang Jagaraga 1 tahun 1848 prajurit Bali dapat mengusir Belanda. Jumlah prajurit Buleleng, Karangasem, dan Klungkung sekitar 7 sampai 8.000. Jumlah ini jauh lebih besar dari yang diperkirakan Belanda. Pada tanggal 20 juni 1848 pasukan Belanda meninggalkan Bali. Kekalahan ini menyebabkan pemerintah Hindia Belanda mengirimkan ekspedisi yang ketiga pada tahun 1849, yang kemudian disebut Perang Jagaraga II. Pada tanggal 16 april 1849 adalah hari jatuhnya benteng Jagaraga ke tangan Belanda.

Kekalahan laskar Jagaraga dikarenakan persenjataan Bali jauh lebih rendah dari segi jumlah maupun kualitas bila dibandingkan dengan persenjataan Belanda dan setelah kemenangan dalam Perang Jagaraga 1 pada tahun 1848 Patih Jelantik kurang mengadakan pembinaan wilayah terutama wilayah yang merupakan sayap perbatasan yang menjadi wilayah kontak senjata terutama desa Sangsit yang terletak di pantai Sangsit.

Setelah Perang terjadi pada tahun 1884-1885 di Desa Jagaraga berlalu, kenangan dari kisah para pejuang dalam usahanya melawan penajajah Belanda masih ada di benak masyarakat di Desa Jagaraga. Dalam upaya mengenang, menghormati dan mengabadikan jasa-jasa para pejuang yang telah gugur sebagai pahlawan kusuma bangsa pada masa perjuangan di Bali, maka timbullah gagasan untuk mendirikan sebuah monumen perjuangan di Desa Jagaraga yang sekarang Monumen Perang Jagaraga.

Monumen ini mulai dibangun pada bulan agustus 2016 dengan anggaran dari pemerintah Provinsi Bali, Dana yang disiapkan untuk pembangunan monumen ini senilai Rp.15 milliar. Monumen yang tingginya 15 meter itu dibangun di lahan seluas 0,5 hektar. Di 
Monumen dibuat patung dua tokoh pejuang perang Jagaraga, yakni Gusti Ketut Jelantik (Mahapatih Kerajaan Buleleng) dan Jro Jempiring. Kedua tokoh dari trah Semeton Arya Pangalasan ini memegang peran penting dalam Perang Puputan Jagaraga melawan Belanda tahun 1849. pada 9 Juni 1848 terjadi peperangan heroik yang dilakukan rakyat Jagaraga dalam mengusir penjajah Belanda.

Berdasarkan latar belakang tersebut, perjuangan heroik dalam perang di Buleleng merupakan sejarah pertama masuknya penjajah Belanda ke Bali

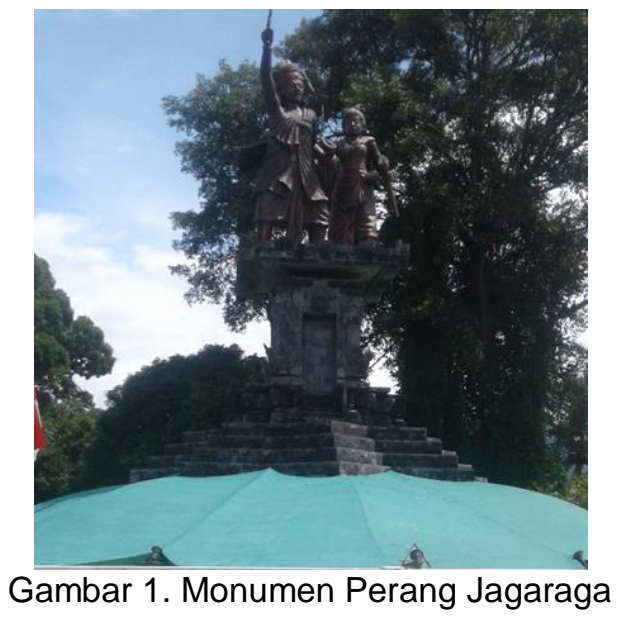

Beberapa faktor yang melatarbelakangi pendirian monumen Jagaraga ini, antara lain sebagai peringatan terhadap suatu peristiwa dan sebagai penghargaan serta penghormatan jasa-jasa para pahlawan yang gugur dalam pertempuran melawan Belanda.

\section{Nilai-Nilai Karakter yang Terkandung Dalam Monumen Perang Jagaraga}

Religius sebagai salah satu nilai karakter sebagai sikap dan prilaku yang patuh dalam melaksanakan ajaran agama yang dianut, toleran terhadap pelaksanaan ibadah lain, dan hidup rukun dengan pemeluk agama lain. Sikap religius juga dapat dilihat dari dioramadiorama yang menginspirasi dan menjadi panutan banyak orang. Sikap religius ini dapat terlihat dari I Gusti Ketut Jelantik selalu bertakwa Kepada Tuhan Yang Maha Esa sesuai dengan kepercayaan yang dianut. Secara kepercayaan I Gusti Ketut Jelantik menganut agama Hindu. Hal ini dapat dibuktikan dari buku Perang Jagaraga Sogiyono (2011: 100) dijelaskan bahwa I Gusti Ketut Jelantik sering berkunjung ke Pura Manasa yang berada di Desa Sinabun untuk melakukan pemujaan sebelum Perang Jagaraga.

Toleransi adalah suatu sikap atau perilaku manusia yang tidak menyimpang dari aturan, dimana seseorang menghargai atau menghormati setiap tindakan yang orang lain lakukan. Sikap toleransi sangat perlu dikembangkan karena manusia adalah mahluk sosial dan akan menciptakan adanya kerukunan hidup. Toleransi bermakna sebagai suatu bentuk sikap atau kondisi kemasyarakatan. Toleransi sebagai kondisi kemasyarakatan berhubungan erat dengan sikap yang dianut secara luas dikalangan masyarakat. Toleransi dalam hal ini berarti suatu sikap menerima pihak lain dan menghargai perbedaan. Sikap toleransi yang terdapat pada Monumen Perang Jagaraga ditunjukkan dengan menghargai perbedaan pendapat. Gagasan ini dibuktikan dari uraian Soegianto dalam perang Jagaraga (2011: 43), pada tahun 1841 saat keempat raja yang mempunyai pelabuhan-pelabuhan penting dapat dibujuk untuk menandatangani perjanjian oleh pihak Belanda.

Jujur, jika diartikan adalah mengakui, berkata atau memberikan suatu informasi yang sesuai dengan kenyataan dan kebenaran. Jujur adalah suatu karakter yang berarti berani menyatakan keyakinan pribadi menunjukkan siapa dirinya. Kejujuran adalah sikap yang mencerminkan keselarasan ucapan dengan perbuatan. Ada 3 tingkatan kejujuran diantaranya, jujur dalam ucapan yaitu kesesuaian ucapan dengan realita, jujur dalam perbuatan yaitu kesesuaian antara ucapan dengan perbuatan dan jujur dalam niat yaitu kejujuran tertinggi dimana ucapan dan perbuatan semuanya hanaya untuk Tuhan Yang 
Maha Esa. Sikap jujur didasarkan upaya menjadikan dirinya sebagai orang yang selalu dipercaya. Sikap jujur dari I Gusti Ketut Jelantik terlihat dari jabatan yang diembannya. Tanpa sikap kejujuran tidak akan mungkin seseorang akan mudah dipercaya dan menduduki jabatan sebagai seorang Patih Agung yang mendampingi Raja Buleleng

Kerja keras adalah kegiatan yang dikerjakan secara sungguh-sungguh tanpa mengenal lelah atau berhenti sebelum target kerja tercapai dan selalu mengutamakan dan memperhatikan kepuasan hasil pada setiap kegiatan yang dilakukan. Sikap kerja keras ditunjukkan dalam diorama yang ada pada Monumen Perang Jagaraga saat para pasukan para pejuang Perang Jagaraga berusaha membangun benteng-benteng pertahanan agar tidak mudah untuk diserang oleh serdadu Belanda. Hal ini dapat dilihat dari hasil buku Soegianto dalam Perang Jagaraga (2011:57) disampaikan bahwa setelah perang Buleleng pada tahun 1846 terjadi, Belanda berhasil menduduki daerah Buleleng. Hal ini dapat dibuktikan dalam diorama yang ada pada Monumen Perang Jagaraga pada gambar 2.

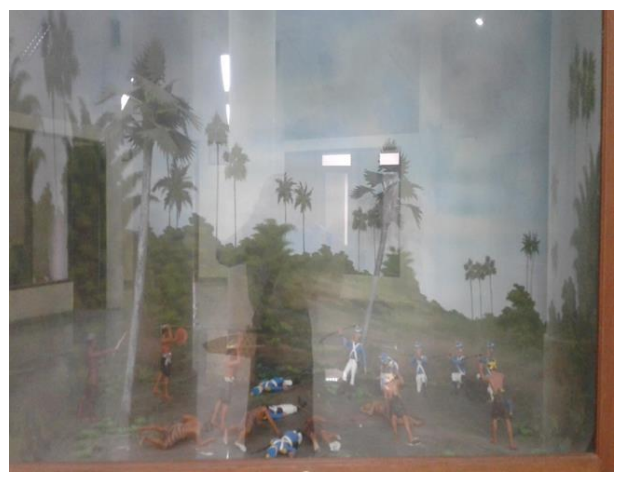

Gambar 2. Diorama Perang Jagaraga

Kreatif adalah kemampuan untuk memberikan suatu gagasan baru dalam pemecahan masalah. Kreatif merupakan kemampuan untuk menciptakan hal-hal baru atau cara-cara baru dari suatu yang sudah ada sebelumnya. Sikap kreatif ini bisa dilihat dalam diorama dalam Monumen Perang Jagaraga, dimana dalam diorama tersebut pasukan Perang Jagaraga membuat taktik perang atau benteng pertahanan yang dipandu oleh I Gusti Ketut Jelantik. Benteng Jagaraga yang iya rencanakan merupakan benteng yang kuat dan sukar ditembus oleh musuh. Strategi pertahanan beliau yang sangat terkenal ialah sistem pertahanan "Supit udang" atau Makara Wyuha. Dari sistem pertahanan tersebut terlihat bagaimana perhitungan yang dilakukan para prajurit Perang Jagaraga. Selain itu pemilihan tempat yang tepat untuk pembuatan benteng juga membantu dalam keberhasilan sistem pertahanan "Supit Urang" Makara Wyuha dalam Perang Jagaraga 1. Sikap kreatif ini bisa dilihat pada gambar 3 .

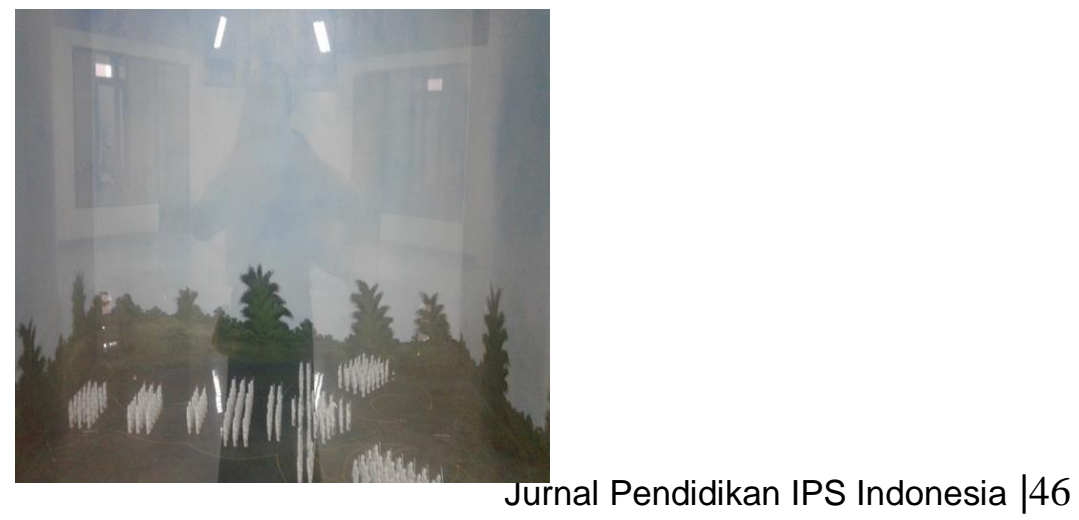




\section{Gambar 3. Diorama Makara Wyuha}

Semangat kebangsaan adalah suatu keadaan yang menunjukkan adanya kesadaran untuk menyerahkan kesetiaan tertinggi dari setiap pribadi terhadap Negara atau Bangsa. Pengertian ini sejalan dengan makna semangat kebangsaan yang identik dengan konsep nasionalisme dan patriotisme. Nasionalisme adalah suatu paham yang menganggap bahwa kesetiaan tertinggi atas setiap pribadi wajib diserahkan kepada negara kebangsaan. Sedangkan patriotisme berarti semangat cinta tanah air atau sikap seseorang yang bersedia mengorbankan segala-galanya untuk mempertahankan bangsanya.

Sikap semangat kebangsaan dari gambaran diorama yang ada dalam Monumen Perang Jagaraga yakni sifat patriotisme yang tampak dalam perjuangan menentang penjajahan Belanda dari tahun 1846-1849 dalam Perang Buleleng dan Perang Jagaraga. Keberanian para prajurit yang digambarkan dalam diorama Monumen Jagaraga berhadapan dengan kekuatan super power, mengambil resiko dengan bersikap tegas tanpa kompromi mempertahankan dan membela kedaulatan tanah airnya, bangsa dan kerajaannya. Sikap semangat kebangsaan yang tergambar dalam diorama bisa dilihat pada gambar 4 .
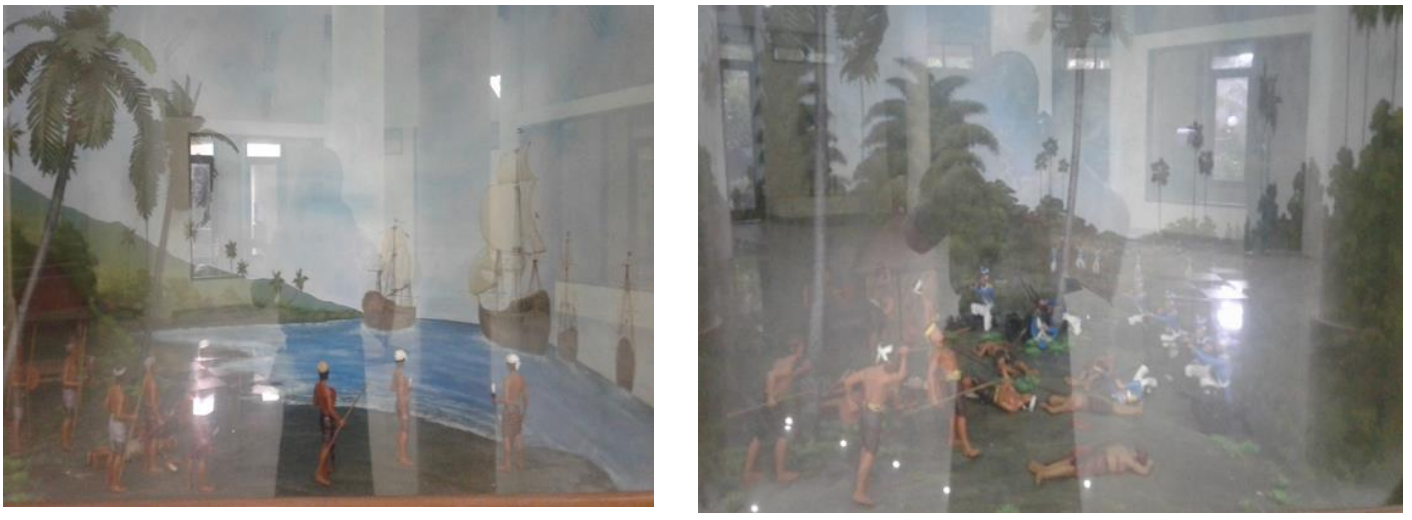

Gambar 4. Diorama Kembalinya Ekspedisi Militer Belanda

Cinta tanah air adalah perasaan yang timbul dari dalam hati seseorang warga negara untuk mengabdi, memelihara, membela, melindungi tanah airnya dari segala macam bentuk ancaman dan gangguan. Sikap cinta tanah air dari I Gusti Ketut Jelantik ialah sifat rela berkorban untuk kepentingan rakyat, membela kebenaran, menjunjung tinggi martabat manusia dan harga diri, ini terkandung sifat beliau yang anti penjajahan. Dalam perlawanannya itu tampak sifat ksatria dan gagah berani dan sifat pantang menyerah. Sikap cinta tanah air ini juga tampak saat Belanda menentang dan memerintahkan Buleleng untuk menghapus Hak Tawan Karang, Jelantik dengan beraninya mengatakan hal itu tidak akan terjadi sampai Belanda bisa melangkahi mauat beliau.

Cinta damai adalah cinta yang mengedepankan perdamaian dalam berinteraksi terhadap sesama umay manusia. Cinta damai yaitu orang yang bisa menghargai perbedaan yang dimiliki individu atau kelompok lain daripada dirinya atau kelompoknya sendiri. Menghargai dalam artian seseorang tidak asal menjude atau menghina perbedaan yang ada pada orang lain apalagi sampai melakukan kekerasan terhadap orang lain. Manusia tidak perlu menjadi orang yang ramah tamah, suka memuji, maupun menyapa tetapi manusia harus menjaga perbuatannya baik perkataan maupun perbuatan dari kekerasan yang merugikan orang lain. Sikap cinta damai dalam diorama Monumen Perang Jagaraga tercermin dari tindakan yang tidak ingin Bali dikuasai oleh Belanda. Kedamaian akan terjadi ketika tidak ada lagi penjajahan oleh Belanda. Kedatangan Belanda kembali dan niatnya untuk menghapus hak tawan karang dianggap mengganggu kedamaian. Sikap anti Belanda ini ditunjukkan dengan melakukan perlawabab, bahkan setiap ajakan untuk berunding. Sikap cinta damai ini bisa dibuktikan dengan diorama Monumen Perang Jagaraga pada gambar 5. 


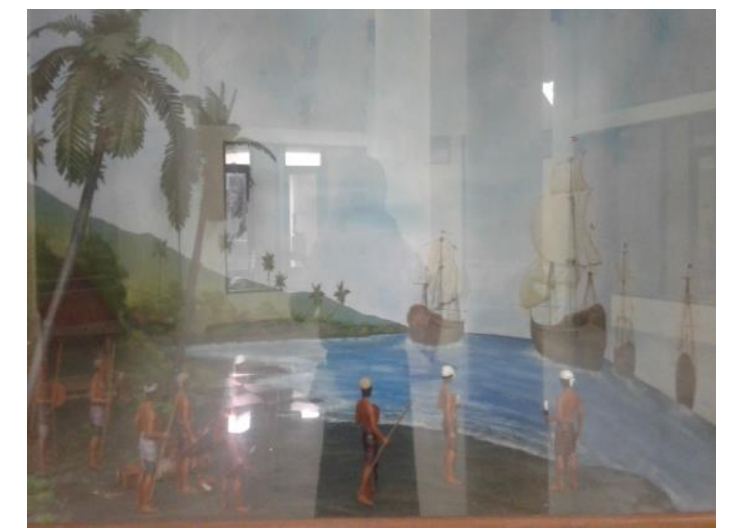

Gambar 5. Diorama Perang Puputan di Desa Jagaraga

Tanggung jawab adalah kesadaran manusia akan tingkah laku atau perbuatan yang disengaja maupun tidak disengaja. Tanggung jawab adalah ciri manusia beradab (berbudaya). Manusia merasa bertanggung jawab karena ia menyadari akibat baik atau buruk perbuatannya dan menyadari pula bahwa pihak lain memerlukan pengabdian atau pengorbanannya. Tanggung jawab dapat dibedakan menurut keadaan manusia atau hubungan yang dibuatnya, yaitu terhadap masyarakat, tanggung jawab terhadap bangsa dan negara dan tanggung jawab kepada Tuan Yang Maha Esa. Sikap tanggung jawab yang ada pada diorama Monumen Perang Jagaraga ketika menetang penjajahan Belanda diawali dengan menolak tuntutan Belanda yaitu mengganti kerugian atas kapal-kapal yang dirampas dan mengakui kedaulatan Belanda di Buleleng. Tanggung jawab Pejuang Perang Jagaraga berani mengambil resiko terhadap apapun yang terjadi di ilustrasikan pada gambar 6 .

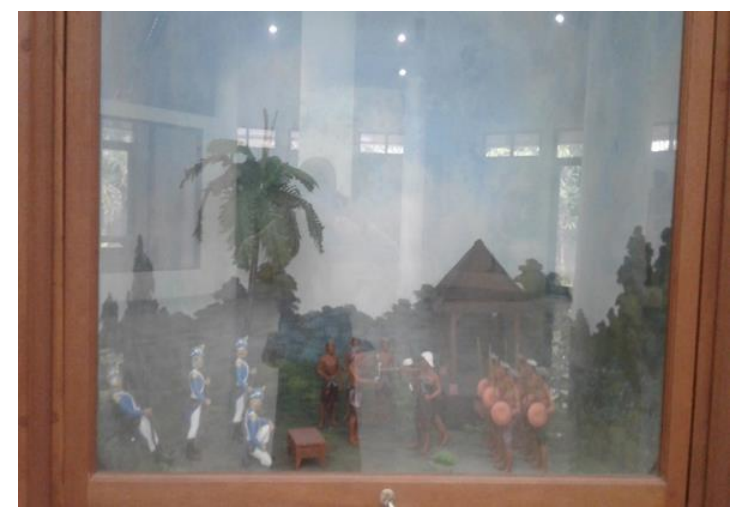

Gambar 6. Diorama Perundingan antara Kerajaan Buleleng dan Pihak Belanda

\section{Pengintegrasian nilai-nilai karakter pada monumen perang jagaraga sebagai sumber pembelajaran IPS.}

KTSP adalah Kurikulum Tingkat Satuan Pendidikan merupakan sebuah kurikulum operasional pendidikan yang disusun oleh dan dilaksanakan di masing-masing satuan pendidikan di Indonesia. Kurikulum Tingkat Satuan Pendidikan (KTSP) mata pelajaran IPS SMP memiliki lima ruang lingkup materi meliputi, (1) Sistem sosial dan budaya, (2) Manusia, Tempat dan Lingkungan, (3) Perilaku Ekonomi dan Kesejahteraan, (4) Waktu, Keberlanjutan dan Perubahan, dan (5) Sistem Berbangsa dan Bernegara. Dalam penelitian ini yang akan dianalisis adalah kurikulum untuk kelas VIII. Di kurikulum IPS kelas VIII semester genap terdapat 7 Standar Kompetensi dilengkapi dengan Kompetensi Dasar. Standar Kompetensi yang digunakan dalam penelitian ini adalah Standar Kompetensi yang ke 5 yaitu Memahami usaha persiapan kemerdekaan dengan Kompetensi Dasar Mendeskripsikan peristiwaperistiwa sekitar proklamasi.

Silabus merupakan perangkat pembelajaran yang berasal dari turunan kurikulum. Dalam penelitian ini silabus yang digunakan adalah silabus IPS semester 2 dengan Standar 
Kompetensi memahami usaha persiapan kemerdekaan. Kompetensi Dasar dalam silabus yang dipilih untuk penelitian ini adalah mendeskripsikan peristiwa-peristiwa sekitar proklamasi. Materi pokok adalah tindakan heroik di berbagai daerah. Selanjutnya lewat silabus tersebut kita juga dapat membuat Rencana Pelaksanaan Pembelajaran (RPP) yang akan diterapkan di dalam kelas VIII yang memfungsikan keberadaan Monumen Perang Jagaraga sebagai sumber belajar IPS.

Silabus didalam kurikulum Tingkat Satuan Pendidikan tidak dapat dikembangkan oleh guru, sebab sudah disusun secara sistematis oleh pemerintah ditingkat nasional . Oleh karena itu, hanya RPP yang dapat dikembangkan secara mandiri atau kelompok oleh guru disetiap sekolah masing-masing yang disesuaikan dengan tuntutan dan kebutuhan dari siswanya. Dalam pengembangan inilah peninggalan sejarah yang berupa monumen dapat diintegrasikan pada kompetensi dasar. Setelah menunjukkan keterkitan KD dengan Monumen Perang Jagaraga maka langkah selanjutnya adalah mengintegrasikannya kedalam kurikulum Tingkat Satuan Pendidikan dalam bentuk Rencana Pelaksanaan Pembelajaran.

Penerapan Sejarah Monumen Perang Jagaraga, berpijak pada pendekatan proses Kurikulum Tingkat Satuan Pendidikan (KTSP) Ilmu Pengetahuan Sosial SMP, sehingga pelaksanaannya terintegrasi dalam pembelajaran IPS.

Materi yang dikembangkan dengan menggunakan buku pegangan guru dan siswa, serta menggunakan lembar kerja siswa (LKS). Sementara itu nilai-nilai pendidikan yang dikembangkan adalah berasal dari nilai-nilai karakter yang ada pada Monumen Perang Jagaraga. Nilai-nilai tersebut secara material dipadukan ke dalam Kompetensi Dasar (KD) IPS kelas VIII Semester 2.

Pelaksanaan pembelajaran nilai ini dilakukan dengan pembagian alokasi waktu pembelajaran yang dibuat oleh guru mata pelajaran IPS kelas VIII di SMP Negeri 1 Sawan. Jadi alokasi waktu yang digunakan pada materi pembelajaran "tindakan heorik di berbagai daerah " adalah 2 jam pelajaran atau $2 \times 45$ menit.

Jagaraga sebagai sumber pembelajaran IPS, dimulai dengan menceritakan tentang latar belakang sejarah dibangunnya Monumen dan diharapkan siswa dapat memahami dan menganalisis nilai-nilaiyang terkandung dalam Monumen Perang Jagaraga tersebut. Untuk memperoleh alur cerita yang tertata rapi dan apik sesuai harapan, maka dibuatkanlah sebuah scenario kegiatan pembelajaran yang disesuaikan dengan metode pembelajaran yang diterapkan.

Evaluasi proses yang berpijak pada kegiatan peserta didik adalah kegiatan yang dilakukan peserta didik selama proses pembelajaran dikelas. Sementara itu pengukurannya dilakukan dengan menggunakan lembar observasi, tes kognitif, dan tes sikap, evaluasi hasil, yakni penguasaan kompetensi peserta didik adalah mengikuti KD ( Kompetensi Dasar) dan tujuan pembelajaran IPS kelas VIII Semseter 2.

Dengan menariknya pembelajaran dan bertambahnya wawasan siswa terhadap lingkungan sekitar, diharapkan tujuan dari pendidikan IPS yang berupaya melahirkan peserta didik yang bukan berkarakter dan berahlak mulia, tetapi juga melahirkan peserta didik yang memiliki jati diri dan mencintai kekayaan daerahnya yang sedari awal dikenalkan melalui pembelajaran IPS berbasis peninggalan sejarah yang bermuatan dengan pembelajaran nilai PENUTUP

Simpulan pada penelitian ini adalah Sejarah perang jagaraga dilatar belakangi oleh dihapuskannya hak tawan karang oleh pihak Belanda akan tetapi Raja buleleng tidak setuju sehingga terjadilah perang Jagaraga pada tahun 1849. Selain itu, terdapat beberapa nilainilai karakter pada diorama-diorama yang ada pada monumen perang jagaraga yakni: nilai religius, jujur, toleransi, kerja keras, kreatif, semangat kebangsaan, cinta tan tanah air, bersahabat atau komunikatif, cinta damai dan bertanggung jawab. Selanjutnya, monumen perang Jagaraga digunakan sebagai sumber belajar IPS di SMP yang penerapannya dilakukan dengan menyesuaikan pada Kompetensi dasar di dalam RPP yang digunakan dalam kegiatan pembelajaran. Oleh karena itu, Monumen perang Jagaraga digunakan sebagai sumber belajar IPS di SMP yang penerapannya 
dilakukan dengan menyesuaikan pada Kompetensi dasar di dalam RPP yang digunakan dalam kegiatan pembelajaran

Saran pada penelitian ini adalah diharapkan lebih maksimal lagi dalam pelaksanaan pemanfaatan situs sejarah sebagai sumber belajar sehingga efektifitas baik dalam proses maupun hasilnya dapat tercapai dan diharapkan lebih fokus dan serius dalam pelaksanaan pembelajaran IPS dengan memanfaatkan situs sejarah seperti monumen yang ada di desa jagaraga sebagai sumber belajar

\section{DAFTAR RUJUKAN}

Heri Gunawan. 2012. Pendidikan Karakter; Konsep dan Implementasi. Bandung. Alfabeta

Sastrodiwiryo, Soegianto, Perang Jagaraga (1846-1849) kisah heroik Patih Jelantik dari Bali dalam melawan tentara Belanda, $B P$.

Suprijono, Agus. 2010. „Pemanfaatan Situs Sejarah untuk Mengembangkan Pembelajaran Sejarah Bermakna". Makalah disajikan dalam Seminar Nasional Penemuan Situs-situs baru dan Pemanfaatannya sebagai Sumber Belajar, UNNES, Semarang 8 Mei.

Soegianto. 2011. Perang Jagaraga (1846-1849). Denpasar: Pustaka Bali Post.

Tim Penyusun. 1980/1981. Sejarah Perang Jagaraga. Bali: Proyek APBD. Prop. Dati 1. 